\title{
대순사상에 있어서 종교다원주의 패러다임의 가능성에 대한 연구
}

\author{
김 승 철
} 난잔대학 · 교수

\author{
I. 들어가는 말 \\ II. 기독교와 종교다원주의 \\ III. 한국의 종교적 풍토와 종교다원주의
}

\author{
IV. 대순사상의 종교다원주의 \\ V. 결론을 대신하여: 대순사상과 종교 \\ 다원주의 논의를 위한 과제
}

\section{I. 들어가는 말}

본 소고는 현금 전 지구적인 차원에서 사회적으로나 문화적으로, 그 리고 특히 종교적인 면에 있어서 중요한 과제로서 부상되어 있는 종교 간의 대화(interreligious dialogue)나 종교다원주의(religious pluralism) 를 설명해 줄 수 있는 패러다임을 모색하기 위한 것이다. 이를 위해서 본고는 19 세기 말이라는 역사적 상황을 배경으로 탄생한 한국의 신종교 (新宗㸚)가 타종교와의 관련성 속에서 자기 자신을 어떻게 이해하였는가 를 고찰해 보고자 한다.1) 특히 증산(鼽山) 강일순(姜一淳, 1871-1909)

1) “신종교”라는 용어를 둘러싼 논의와 그 외연(外延)에 대해서는 노길명, 「한국 신종교 운동의 성격」, 『대순사상논총』 7 (1999), pp.585-607을 참조하시오. 노길명은 한국 의 신종교에 대해서 발생사적 관점으로부터의 고찰과 교리와 사상을 분석하는 작업 이 동시에 요구된다고 본다. 본 소고에서는 주로 후자의 연구를 중심으로 하였다. 
의 종교적 자각에 그 연원을 두고 있는 대순사상(大巡思想)의 종교이해 를 살펴봄으로서, 한국의 신종교 운동에서 제시된 종교이해가 종교적으 로 다원화된 현대 사회가 안고 있는 종교적 과제에 대해서 대답해 줄 가능성을 제공해 줄 수 있는지에 대해서 검토해 보고자 한다.

본고의 이러한 목적설정은 대략 다음과 같은 두 가지의 문제의식으 로부터 비롯된 것이다.

첫째, 우리들은 그 동안의 종교간의 대화나 종교다원주의의 역사를 비판적으로 회고해 봄으로서, 종교간의 대화와 종교다원주의를 둘러싼 지금까지의 논의의 공(功)과 과(過)를 동시에 파악하고자 한다. 종교적 으로 다원화된 현대 사회에 있어서 종교다원주의라는 현상에 대한 연 구가 다각도로 이루어져 왔음은 주지의 사실이다. 포스트모더니즘(post -modernism)이나 포스트콜로니알리즘(post-colonialism) 등, 이른바 일 련의 '포스트' 사상군(思想群)의 등장, 그리고 그러한 사상군과 맥락을 같이 하는 해체주의 혹은 탈구축주의(deconstructionism)에 대한 활발 한 논의는, 지금까지 철학이나 문학, 사회학, 예술, 그리고 종교학 등 의 분야에서 보편성을 담지(擔持)한다고 여겨져 온 하나의 '거대 담론' (meta-narrative) 밑에서 변방(邊旁)으로 치부될 수밖에 없었던 국지 적인 '작은 이야기들'에 초점을 맞추려는 시도들로 이어졌다.2) 종교다 원주의에 대한 언설(言說)은, 비록 그것이 종교나 신앙의 본질에 대한 물음을 통해서 이미 다양하게 제기되어 왔다고 하더라도, 역시 이러한 일련의 '포스트' 사상군과 해체주의의 등장에 의해서 더욱 활발해졌던 것도 사실이다.

그런데 포스트모더니즘은 '거대 담론'이 '작은 이야기들'로 해체되는 논리와 그 당위성을 역설한다는 점에서는 근본적으로는 다원주의적

2) 기독교 신학 분야에서 쟈크 데리다(Jacques Derrida)의 해체주의를 신학적으로 수 용한 대표적인 예로서는 미국의 신학자 마크 테일러를 들 수 있을 것이다. Mark C. Taylor, Erring: A Postmodern a/theology, Chicago: University of Chicago Press, 1987; 졸고, 「무주(無住)와 방황(彷得): 즉비(師非)의 논리와 해체의 신학」, 『종교신 학연구』8 (1995), pp.153-205 참조. 
대순사상에 있어서 종교다원주의 패러다임의 가능성에 대한 연구 / 김승철 3

발상으로 이어질 가능성이 있다고 하겠으나, 이 또한 계몽주의 이래 지속되어 온 서구의 역사의식 자체의 연장선 상에서 비롯된 발상에 지 나지 않는다는 지적이 엄존(儼存)하는 것 또한 사실이다. 종교다원주의 에 대한 논의에 한정해서 보더라도, 그와 같은 논의가 아무래도 서구 의 기독교를 중심으로 이루어져 왔으며, 따라서 논의의 틀과 장(場) 역 시 서구의 기독교에 의해서 형성되어 왔음도 또한 역사적 사실로서 인정하지 않으면 안 될 것이다. 3 ) 특히 가톨릭 교회가 제2차 바티칸공 의회를 통해서 천명(闡明)한 “기독교 이외의 종교에 대한 교회의 입 장”(Nostra Aetate, 1965)이라는 선언이 종교간의 대화가 본격적으로 활발하게 이루어지기 위한 신호탄이 되었다는 사실은, 종교간의 대화 나 그러한 종교간의 대화의 가능 근거로서의 종교다원주의에 대한 논 의의 배경과 그 후의 진전양상을 이미 함축하고 있다고 하겠다. "기독 교 이외의 종교에 대한 교회의 입장”은 오늘날 세계의 종교적 상황을 주시하면서 이를 기독교 신학적인 입장에서 수용하려는 자세를 다음 과 같은 언사로 설명하고 있다.

“인류가 날로 더욱 긴밀히 결합되고 여러 민족들 사이의 유 대가 더욱 강화되어 가는 현대에 있어서 교회는 비그리스도교 적 타 종교에 대한 스스로의 태도를 진지하게 검토하는 바이다. 인간과 인간, 민족과 민족 사이의 일치와 사랑을 도모해야 할 사명감을 느끼며 교회는 여기서 특히 모든 사람에게 공통되는 것, 즉 모든 사람을 공동목적으로 이끌어 주는 것들을 검토한 다. (중략) 사람들은 어제도 오늘도 인간의 마음을 번민케 하는 인생의 숨은 수수께끼들의 해답을 여러 가지 종교에서 찾고 있 다. (중략) 가톨릭 교회는 이들 종교에서 발견되는 옳고 성스러 운 것은 아무 것도 배척하지 않는다. 그들의 생활과 행동의 양 식뿐 아니라 그들의 규율과 교리도 거짓 없는 존경으로 살펴본 다. 그것이 비록 가톨릭에서 주장하고 가르치는 것과는 여러 면 에 있어서 서로 다르다 해도 모든 사람을 비추는 참 진리를 반

3) John Hick, A Christian Theology of Religions (Louisville, KY: The Rainbow of Faiths Westminster John Knox Press, 1995), p.31ff. 
영하는 일도 드물지는 않다. 그리스도는 "길이요 진리요 생명이 시며”(요한복음 14장 6절) 그분 안에서 사람들의 종교 생활의 풍 족함을 발견하고 그분 안에서 하느님께서 모든 것을 당신과 화해 시키셨음을(고린도후서 5장 18-19절) 교회는 선포하고 있으며 또 반드시 선포해야 한다." ${ }^{4}$

이 선언문이 포함하고 있는 신학적, 교회적 배경이나 그 의미의 사 정(射程)에 대한 논의는 별개의 것으로 하더라도, "기독교 이외의 종 교에 대한 교회의 입장”이라는 선언은 종교간의 대화나 종교다원주의 를 위한 담론형성에 있어서 기독교가 이룩한 획기적인 성과를 말해준 다는 점에 대해서는 재언의 여지가 없을 것이다.5) 그와 동시에 우리 들은 종교간의 대화나 종교다원주의에 대한 논의의 틀과 장이 기독교 를 중심으로 이루어져 왔다는 사실을 역사적으로 인정하면서도, 또한 그의 한계와 과제를 분명히 하지 않으면 안 된다. 우리들의 과제는 이 러한 주장이 타당성을 지닐 수밖에 없는 신학적이고 역사적 배경을 적시하는 일이다. 다음 절에서는 이에 대해서 약술해 봄으로서 이를 극복할 수 있는 대안을 제시하기 위한 바탕으로 삼고자 한다. 이에 대 해서는 제2절에서 자세하게 논하고자 한다.

둘째, 한국에서 등장한 신종교 운동이 담지하는 종교사상에서 종교 간의 대화나 종교다원주의의 가능성 여부를 모색해 보려는 것은, 한국 의 신종교가 태동한 사회적, 역사적, 종교적 배경에 대한 이해를 전제 로 한다. 구한말이라는 역사적 격동기에 등장한 한국의 신종교는 요원 의 불길처럼 퍼져나가면서 대중들의 영혼을 사로잡았다. 그리고 이러 한 신종교 운동이 대중들 속에 뿌리를 내릴 수 있었다는 사실은 다음

4) Vatican Council, 『제2차 바티칸 공의회 문헌: 헌장, 교령, 선언문』(서울: 한국천주 교중앙협의회, 1969), pp.607-608.

5) "기독교 이외의 종교에 대한 교회의 입장"이 발표되기까지의 공의회 내부에서의 논의 의 과정과 그 신학적 의미에 대해서는 H. V. 스트라렌 외, 『공의회 문헌해설 총서』1, 현석호 역 (서울: 성바오로출판사, 1982), p.421 이하를 참조. 또 졸고, 종교다원주 의와 한국신학의 방향, 우리사상연구소 편, 『한국 가톨릭 어디로 갈 것인가』(서울: 서광사, 1997), p.373 이하도 참조하시오. 
과 같은 사실을 우리에게 의미한다. "조선 후기의 신종교 운동이 당시 의 사회변동과 밀접한 관련 하에서 전개되어 나갔다면, 그것은 당시의 민중들의 의식수준이 그에 상응하였기 때문이며, 그 의식수준 또한 민 중들의 사회 현실적인 체험들이 자연스럽게 모여서 이루어지게 된 것 이다.”6) 신종교 운동이, ‘운동’이라는 명칭 자체에서도 충분히 유추할 수 있는 것처럼, 단순히 종교이론을 둘러싼 추상적인 갑론을박(甲論乙 駁)으로서가 아니라 대중들의 '사회 현실적인 체험'의 응축으로서의 '의식수준'의 차원에서 이러졌다는 점이 대단히 중요하다는 말이다.

그런데 이러한 대중들의 '의식수준'과 부합할 수 있었던 신종교 운 동의 특징으로서 이른바 '회통적 다원주의'7)가 거론된다는 점은, 한국 의 신종교 운동에서 나타난 종교이해로부터 종교다원주의를 위한 패 러다임의 가능성 여부를 논하려는 우리들의 의도에 있어서 대단히 중 요한 의미를 지니고 있다. 한국의 신종교 운동은 동양의 전통적 종교 인 유교와 불교와 도교를 하나로 회통(會通)하여 이 전통적 종교의 자 각을 구한말이라고 하는 사회상 속에서 새롭게 이해함으로써, 전통을 창조적으로 극복 내지는 재창조하려 했다고 하는 공통성을 지니고 있 다는 말이다. 본 논문에서 고찰해 보려는 증산의 종교적 자각의 특색 으로서 박광수는 다음과 같이 말하고 있는데, 이 역시 위에서 거론한 신종교적 종교적 자각이 회통사상에 맞닿아 있음을 지적하고 있다. "증산신앙운동을 전개한 증산은 서구종교의 한계를 지적하고 기독교 를 종교적 신념의 근간으로 삼은 서양에 한국을 맡길 수 없는 이유와 서구종교에 대한 비판적 입장을 견지하면서 동양종교의 우수성과 증 산사상의 우수성을 밝히고 있다. 특히 유, 불, 선 삼교 중 선도사상을 중심으로 증산교의 종교회통적 사상을 발전시켰다." 8 )

반복되는 말이 되겠으나, 여기에서 우리들이 주목하고자 하는 것은,

6) 이경원, 『한국 신종교와 대순사상』(서울: 문사철, 2011), p.324.

7) 박광수, 「한국 신종교의 근본주의(Fundamentalism)와 회통적 다원주의(Synthetic Pluralism)」, 『한국종교연구』9 (2007), p.150.

8) 같은 글, p.152. 
동양의 전통적 종교로서의 유교와 불교와 도교라는 이른바 '삼교'(三 敎)를 하나로 원융(圓融) 한다는 발상이 동양적 종교전통의 고유한 특 징의 하나이고, 이것이 한국의 신종교에게 계승되었다고 보는 것이 타 당하다는 점이다. 이에 대해서는 제3절에서 상론할 것이나, 종교다원 주의적 패러다임을 한국의 신종교 속에서 찾을 수 있는가 하는 문제 설정은, 그들 신종교가 태동한 역사적, 사회적 배경을 고려한 것이며, 한국의 신종교라는 현상의 복합성을 고려해 볼 때, 일회적인 연구에서 그 적절한 해답이 도출될 수 없음은 자명한 일이다. 따라서 본고는 앞 으로의 보다 본격적인 연구를 위한 하나의 예비적인 단계의 연구가 될 것이다.

이하에서 우리들은 방금 언급하였던 두 가지 측면에서 종교다원주 의를 위한 패러다임에 대한 논구를 시작하려 한다. 즉 종교다원주의를 둘러싼 담론이 기독교를 중심으로 이루어져 왔던 배경과 경위를 개괄 해 보고(제 2 장), 한국의 신종교가 지닌 종교이해 내지는 궁극적 실재 이해를 고찰해 보고자 한다.(제3장)

그리고 제4절에서는 대순사상 속에 나타난 종교다원주의 이해를 고 찰하고, 결론(제5장)에서 대순사상으로부터 종교다원주의를 보다 적극 적으로 논하기 위한 과제에 대해서 언급하겠다.

\section{II. 기독교와 종교다원주의}

지금까지의 종교다원주의를 둘러 싼 논의가 기독교 중심적으로 이 루어져 왔다는 지적은, 현재 종교학계에서 이루어지고 있는 논의, 특 히 그 가운데에서도 하나의 독립적인 분야로서의 종교학의 등장과 종 교라는 개념의 형성에 대한 자기비판적인 논쟁을 통해서도 그러한 지 적의 타당성이 밝혀진다.9) 구미에서 '종교학'이 하나의 독자적인 학문 
영역으로서 탄생한 이래, 종교학과 기독교 신학과의 관계는 항상 논의의 대상이 되어 왔다. 주지하다시피, '종교학'(science of religion, religious studies[英], Religionswissenschaft[獨])이 하나의 독립적인 학문분야로 서 자리 잡은 배경에는 서구의 식민지에 대한 기독교 선교라고 하는, 정 치적이고 교회적인 상황과 깊은 연관성을 지닌다. 이러한 사실은 종교학 의 탄생에 기독교 신학과 유럽의 정치적 지형(地形)이 깊게 관계되어 있었음을 말해주는 것이기도 하다. 물론 종교학의 내부에서도 신학과 의 관계를 어떻게 설정해야 하는가를 둘러싸고 여러 가지 다양한 견해 가 공존하는 것도 사실이다. 종교학과 신학의 관계에 대한 생각은, 양 자를 상보적이고 협력적 관계로서 파악하는 입장을 필두로 해서, 양자 의 관계를 대결이나 독립이라는 입장에서 바라보는 생각이 공존해 있 어서 결코 일의적이라고는 할 수 없을 것이다.

우리들은 유럽의 여러 대학에서 종교학 강좌가 개설되기 시작했을 때의 양상을 일별해 보는 것만으로도, 종교학과 기독교 신학의 태생적 인 관계를 파악할 수 있다. 유럽에서 처음으로 '종교학 개론'의 강좌 가 개설되었던 것은 1873 년 제네바 대학의 신학부였다. 그로부터 4 년 후 암스테르담에서 신앙 고백과는 관계없이 종교학 강좌가 설치되었지 만, 그 강좌를 담당했던 사람은 신학자인 틸레(Cornelis Petrus Tiele, 1830-1902)와 샹뜨삐 드 라 소세이(Pierre Daniël Chantepie de la Saussaye, 1848-1920)였다. 또 독일에서는 베를린 대학(1910년)과 라이프치히 대학(1912년) 등에서 차례차례 종교학 강좌가 개설되었지 만, 제2차 세계대전 이전까지 본(Bonn) 대학의 경우를 제외하고는 모 두 신학부 내에 개설되었다. ${ }^{10)}$

예를 들어서 독일의 종교학자 프리드리히 하일러(Firedrich Heiler,

9) 이하, 종교학과 신학의 관계에 대한 약술은 졸고, 「E・トレルチの神学思想に扔けるヨー ロッ八゚中心主義について」, 『人文科學』7-1（金城学院大学論集, 2010), pp.47-48를 참조 하면서 이루어졌다. 또한 트뢸치에 대한 아래의 논구도 이 졸고를 중심으로 한 것이다.

10) Axel Michaels, "Einleitung" idem(Hg.), Klassiker der Religionswissenschaft: Von Friedrich Schleiermacher bis Mircea Eliade, 2.Aufl., München: C.H.Beck, 2004, S.7. 
1892 1967)가 종교학과 신학의 관계에 대해서 피력한 다음 문장에 서도 종교학과 신학의 관계가 단적으로 드러난다. 하일러에게 종교학 은 신학에 수렴된다. “종교에 있어서 소중한 것은 인간에게 계시 되어 인간을 압도하는 궁극적 실재이다. 신, 계시, 영원의 삶이라고 하는 것은, 종교적 인간에게 있어서는 현실이다. 종교학이 종교를 심리학적 인, 또 역사학적인 현상으로서 관계하는 것이 아니라, 초월적인 현실 에 대한 경험으로서 취급하는 한, 모든 종교학은 궁극적으로는 신학이 다(“Alle Religionswissenschaft ist letztlich Theologie”). 종교는 확 실히 정신적 삶과 정신의 문화의 일부이며, 나아가 이러한 정신적 삶은 궁극적으로는 형이상학적 근원으로부터 이해할 수 있는 것이다.”11) 종 교학을 신학에 환원시키는 태도는, 스웨덴의 루터파 신학자이며 종교학 의 창시자의 한 사람으로서 꼽히는 나단 죄더블롬 (Nathan Söderblom, 1866-1931)에게서 더욱 두드러지게 된다. 죄더블롬에게 있어서 종교 학은 전통적인 자연신학(theologia naturalis)이 담당하고 있던 역할을 완수하는 것이며, 그러므로 종교사는 신의 보편적 존재와 활동을 나타 내는 장소와 다름없다. 이런 점에서 위의 하일러가 “모든 종교학은 궁 극적으로는 신학이다.”라는 자신의 주장을 뒷받침하기 위하여 죄더블롬 의 다음과 같은 말을 인용한 소이를 이해하게 된다. "나는 신이 살아 계시는 것을 알고 있다. 나는 그러한 사실을 종교사에 의해서 증명할 수 있다."12)

그런데 종교학이 지닌 신학적 연원이라는 사실은 종교학의 탄생에 기독교가 안고 있던 일종의 위기의식이 작용하고 있었다는 역사적 사 실과도 연결된다.13) 이러한 위기의식을 신학적인 사고를 통해서 본격 적으로 직면하고자 하였던 최초의 신학자는 독일의 개신교 신학자 에

11) Friedrich Heiler, Erscheinungsformen und Wesen der Religion (Stuttgart: W. Kohlhammer Verlag, 1961), S.17. (밑줄 친 부분은 인용자의 강조이다.)

12) Edgar Almén, "Nathan Söderblom as a pioneer of religious studies, as a the ologian and as an archbishop of the Church of Sweden", http://www.liu.se/irk /religion/texter/EA/EA99omSoderblom.htm (2010년4월22일)

13）磯前順一,「宗教研究とポストコロニアル状況」, 磯前順一・タラル・アサド編,『宗教 を語りなおすー近代的カテゴリーの再考』(みすず書房, 2006), 7頁. 
대순사상에 있어서 종교다원주의 패러다임의 가능성에 대한 연구 / 김승철 9

른스트 트뢸치(Ernst Troeltsch, 1865-1923)였다. 신학자로서의 트뢸 치에게 절실하였던 문제는 기독교의 절대성이 종교의 역사와 어떻게 관련될 수 있는가 하는 물음에 대한 대답이었다. 이는 기독교의 '계시' 가 인간의 '역사’와 어떻게 연관되는가 하는 고전적인 물음의 카테고 리에 속한다고 할 수 있다. 그는 '계시'와 '역사' 사이의 긴장관계, 다 른 말로 하자면 기독교가 가르치는 신의 계시와 역사 속에서의 다양 한 종교들 사이의 긴장관계를 규명하고자 하였는데, 이러한 맥락에서 저술되었던 것이『기독교의 절대성과 종교사』(1902)였다. 이 책에서 트뢸치는 기독교 신학이 짊어지게 된 새로운 문제의식을 다음과 같이 종합하고 있다.

“교회의 철학과 신학은, 절대적인 기적에 의해서 창건되었으 며, 회심과 비적(秘跡)의 기적에 의해서 스스로를 유지하는 교 회, 즉, 역사 가운데 존재하지만 역사에 유래하지 않는 초자연 적인 제도로서의 교회라고 하는 개념을 완성했다. (중략) 근대 의 역사 연구는 이 변증론적인 사상 구조를 근본적으로 완전하 게 해체시킬 방향으로 작용하였다. (중략) 기독교가 절대적인 종교라는 구상은 역사적인 사고방식으로 보아도, 역사적인 방법 을 통해서 보더라도 더 이상 가능하지 않다. 그리고 이러한 구 상의 불가능 안에 오늘날 학문적인 신학이 불안하고 그림자와 같은 것으로서 느끼는 모든 것이 포함되어 있다.”14)

하지만 트뢸치는 여전히 기독교는 모든 종교적 이상의 수렴점(Kon vergentpunkt)이라는 발상에 집착하고 있었다. 조금 긴 인용이 되겠 으나, 이에 관련한 트뢸치의 진술을 직접 들어 보자. 흔히들 자신의 종교가 다른 종교에 대해서 개방적인 태도를 취한다고 하면서도 내면 적으로는 자신의 종교의 절대적 우위성에 고착하려는 태도를 우리들 은 흔히 만나게 되는데, 그들의 주장 속에는 사실 트뢸치의 목소리가 변형된 형태로 들여온다고 할 수 있기 때문이다.

14) Ernst Troeltsch, Die Absolutheit des Christentums und die Religionsgeschichte (J.C.B. Mohr, 1902), S.12; 45. 
“기독교는 사실 위대한 종교 중에서 인격적인 종교심을 가장 강력하게, 그리고 가장 집중적으로 나타내 보이는 계시이다. 아 니, 그 이상의 것이다. 기독교는 완전히 독특한 위치를 차지한 다. 왜냐하면, 기독교만이 고차원의 세계와 저차원의 세계의 단 절을 모든 곳에서 감득하는 것을 근본적으로 수행했기 때문이 다. (중략) 기독교는 자연 종교의 한계와 제약으로부터 완전하 게 단절한 유일한 종교이며, 고차의 세계를 무한한 가치가 있는 생으로 나타내고, 또 다른 모든 것을 가장 먼저 제약하고 형성 하는 인격적 삶으로서 제시한다. 기독교는 세계를 부정한다. 다 만 자연적인 의미가 세계에 부착해 버리고, 악이 이 세계 속에 서 힘을 발휘하게 되었을 때에만, 기독교는 세계를 부정하는 것 이다. 기독교는 이 세계를 긍정한다. 다만 세계가 신과 경건한 사람들에 의해서 신에게서 유래하고 신으로 돌아가는 것으로서 이해될 때, 기독교는 세계를 긍정한다. 그리고 부정과 긍정이 하나가 된다. 다른 종교에서는 경험되지 못한 힘과 자립성에 의 해서 그것은 진정한 고차의 세계를 나타내는 것이다. (중략) 기 독교는 최고점일 뿐만 아니라, 종교의 모든 인식 가능한 발전 방향의 수렴점(Konvergentpunkt)으로 풍부해지지 않으면 안 된 다. 그러므로 다른 종교와 비교될 때, 여러 종교를 총괄하는 중 심점으로서, 원리상 새로운 삶의 개시로서 나타날 수 있는 것이 다. 그것이 추상적으로 추출된 종교의 보편 개념의 실현과 동의 가 아니라는 점에 대해서는 재언할 필요도 없을 것이다. 기독교 는 확실히 그 특수성 때문에, 그리고 또 종교의 목표를 거기에 서는 문자 그대로 결정적으로 새로운 성질의 것으로 경험하도 록 한다는 현저한 특징을 갖고 있기 때문에 종교사의 최고점에 서는 것이다."15)

하지만 이러한 그의 기독교 중심주의는 만년에 이르러 한 걸음 더 탈 구축의 방향으로 나아가게 되는데, 그러한 사상이 집약적으로 표현된 것 이 그의「세계종교 속에서의 기독교의 위치」(The Place of Christianity among the World Religions; Die Stellung des Christentums unter den Weltreligionen, 1923)라는 논문이었다. 즉『기독교의 절대성과 종 교사』가 "역사적 상대성과 [신앙적] 사실로서의 절대성의 대결에서, 내

15) ibid., S.88-90. 
가 엄밀한 역사학적 연구로부터 이해하게 된 모든 역사 철학의 주요 문 제에 도달하지 않으면 안 되었다.”16)라고 하는 그의 문제의식 아래에 서 집필되면서도 여전히 기독교는 세계종교의 '수렴점'이라는 발상에 머물렀었다고 한다면,「세계종교 속에서의 기독교의 위치」에서는 그러 한 “역사적 상대성과 [신앙적] 사실로서의 절대성의 대결”을 한층 더 자기 비판적으로 추구되었던 것이다.

원래 영국의 옥스포드 대학에서 행할 예정이었던 강연을 위해 집필 되었던 이 논문은, 트뢸치의 뜻하지 않은 급서(急逝)로 인해서 유고 (遺稿)가 되고 말았는데, 이 논문에서 그가 내린 결론은 향후 기독교 와 타종교와의 관계를 적극적으로 수용하려는 이른바 종교다원주의 신학의 원형(元型)으로서 자리매김하였다. 트뢸치는 다음과 같이 말하 고 있다.

“우선 우리에게 진리가 되는 하나의 진리는 그 때문에 진실 과 삶인 것입니다. 그리고 우리가 날마다 다른 사람들에 대한 사랑 속에서 체험하는 것, 즉 다른 사람들은 본질 자체이며 자 기의 척도를 가지고 있는 본질이라는 사실을 우리는 인류에 대 한 사랑 속에서도 체험할 수 있어야만 합니다. 그것은 경쟁을 배제하지는 않습니다. 그러나 그것은 무엇보다도 내적인 정화와 투명함을 위한 경쟁인 것입니다. 만일 우리가 각각의 집단들 속 에서 지고한 것과 가장 깊은 것을 추구한다면, 우리는 만남을 희망해야 할 것입니다. 그것은 크게는 종교들의 만남에 타당하 며, 개개의 종파들의 만남에도 적용되며, 개인들 서로간의 만남 에도 적용됩니다. 신적인 삶은 우리의 이 땅에서의 경험에 있어 서는 하나(Eines)가 아니라 다수(Vieles)입니다. 그러나 다수 속 에서 하나를 예감하는 것(das Eine im Vielen zu ahnen)이야 말로 사랑의 본질입니다."17)

16) Ernst Troeltsch, Meine Bücher (1922), in: Gesammelte Schriften Band IV. A ufsätze zur Geistesgeschichte und Religionssoziologie hg.v. Hans Baron, (J.C. B. Mohr Verlag, 1925)。『私の著書』，荒木康彦 訳 (大阪: 創元社), 1982, 14頁。

17) 김승철 편역, 『종교 다원주의와 기독교 1』(서울: 나단, 1993), pp.103-104. 
대표적인 종교다원주의의 신학자 폴 니터가 지적하고 있듯이, 방금 인용한 트뢸치의 주장은 그 이후의 종교다원주의를 위한 기본 틀을 제공한 것으로 평가된다. "오늘날 우리들이 종교다원주의에 대해서 느 끼고 있는 것의 대부분은 에른스트 트뢸치 안에 반영되어 있었다."18)

그런데 기독교를 중심으로 이루어져 온 종교간의 대화나 종교다원 주의를 둘러싼 담론의 배경을 일별해보는 이유는, 그러한 배경이 동시 에 하나의 한계로서 자각되기 시작하였기 때문이다. 이는 종교다원주 의에 관한 언설(言說)은 진실로 종교간의 대화를 통해서 이루어져야 한다는 자각에서 비롯된 것이기도 하다. 현실적으로는 작금의 종교간 의 대화가 어떤 의미에서는 소강(小康)상태에 들어가지 않았는가 하는 비판적 현실인식의 배경을 이루는 것이기도 할 것이다. 오랫동안 기독 교와 불교의 대화를 이끌어 오면서 일본을 중심으로 활동해 왔던 제 임스 하이직의 다음과 같은 지적은, 종교간의 대화나 이를 통해서 형 성되는 종교다원주의를 둘러싼 언설의 과거와 나아갈 바를 동시에 드 러낸다고 할 수 있다.

“기독교 신학은 종교적으로 다원화된 세계에 있어서 교리적 진리 주장의 본질로부터 파생되는 논의에 집중해 왔기 때문에 만남의 직접성은 만남에 대한 논의로 대체되고 말았다. 시간이 지나 갈수록 불교 측의 대화 참가자들은 기독교인들이 자기 자 신에 대해서 말하기를 더 좋아한다는 사실을 눈치 채기 시작하 였다.”19)

다시 말해서 기독교가 주도해 온 종교간의 대화는 대화를 통한 대 화 참가자간의 상호변혁에 이르기 보다는, 기독교적 진리가 타종교와 어떻게 관계되는가에 대한 기독교적인 관심사로 시종하였다는 말이다.

18) Paul F. Knitter, No Other Name? A Critical Survey of Christian Attitudes T owards World Religions (N.Y.: Orbis Books, 1985), p.23

19) James W. Heisig, "The Misplaced Immediacy of Christian-Buddhist Dialogue", in Catherin Cornille and Stephanie Corigliano, ed., Interreligious Dialogue and Cultural Change (Eugene, OR: Wipf and Stock Publishers, 2012), p.97. 
이렇게 되면 ‘대화의 직접성'은 대화를 통해서 자신의 진리이해가 어 떻게 관철되는가에 대한 관심으로 치환되며, 이 경우 대화에서 자기와 다른 타자의 목소리를 듣는 것은 이미 불가능할 것이다. 이 경우 대화 는 타자와의 만남을 통해서 자신과 타자의 상호변형을 경험하는, 따라 서 대화의 당사자들을 새로움으로 인도하는 장(場)이라기보다는, 사실 한 사람이 자기 자신과 이야기하는 복화술(腹話術, ventriloquism)에 다름 아니다.20) 기독교 신학은 종교적인 대화의 상대자로서 타종교를 자신의 패러다임을 가지고 규정해 놓고 나서, 그러한 상상의 대화 상 대자와 대화하려는 시도를 해오지 않았는가 하는 비판적 자기반성이 이 말에는 포함되어 있다. 그렇게 되면 종교간의 대화에 임한 기독교 신학자가 타종교인에게서 듣고 발견할 수 있는 것은 결국 자신이 이 해하고 있는 기독교 신학일 뿐이다.

알란 레이스가 기독교와 세계종교와의 관계를 배타주의, 포괄주의, 다원주의로 분류한 이후로, 신학자들과 종교학자들은 한 종교가 다른 종교에 대해서 취하는 태도를 이러한 삼분법에 의해서 구분해왔다.21) 어떤 의미에서는 “기독교적인, 너무나도 기독교적인” 이러한 분류법은 별다른 비판 없이 자명한 것으로서 신학자들 사이에서 회자되어 왔던 것이다. 동일한 맥락에서 탈(脫)오리엔탈리스트이자 포스트 콜로니알 리스트인 인도의 종교학자 발라강가다라의 다음과 같은 지적은 기독 교 중심적인 종교다원주의의 논의의 틀을 의문시하는 우리들의 문제 의식을 촌철살인적으로 적확(的確)하게 드러내 준다.

“유럽인들이 우리들 인도에 대해서 알고 있다고 생각하는 것 은, 우리들에게 인도에 대해서 말해주기 보다는 유럽에 대해서 말해주고 있다.”22)

20) Seung Chul Kim, "How could we get over the monotheistic paradigm for the interreligious dialogue", Journal of Inter-religious Studies 13 (2014), p.20.

21) Alan Race, Christians and Religious Pluralism: Patterns in the Christian theo logy of religions (N.Y.: Orbis Books, 1983).

22) S. N. Balagangahara, Reconceptualizing India Studies (Oxford: Oxford University Press, 2012), p.5. 
우리들은 위의 발라강가하라의 말을 파라프레이즈하여 기독교 중심 적인 종교간의 대화나 종교다원주의를 둘러싼 언설에 대해서 다음과 같이 말할 수 있을 것이다. "기독교인들이 종교간의 대화나 종교다원 주의에 대해서 알고 있다고 생각하는 것은, 우리들에게 종교간의 대화 나 종교다원주의에 대해서 말해주기 보다는 기독교에 대해서 말해 주 고 있다."

\section{III. 한국의 종교적 풍토와 종교다원주의}

제 1 장에서 잠시 언급하였던 것처럼, 한국의 신종교는 전통적인 종 교이해를 배경으로 하면서도, 그러한 전통종교에 대한 비판적 수용과 새로운 종교관의 전개의 가능성을 발생론적으로 지니고 있었다는 점 에서 특히 종교다원주의와 관련성 속에서 고찰될 가치와 필요성이 있 다.

그렇다면 증산의 종교적 자각에서 비롯된 대순사상은 현금 요구되 고 있는 종교다원주의에 대해서 어떤 메시지를 전해주고 있는가?

이점과 관련해서 가장 먼저 주목되는 것은 증산이 언급하는 '상생' (相生)의 사상이다. 증산사상의 핵심이라고도 여겨지는 '상생'에 대하 여『전경』은 다음과 같이 말한다.

"인간 사물이 모두 상극에 지배되어 세상이 원한이 쌓이고 맺혀 삼계를 채웠으니 천지가 상도(常道)를 잃어 갖가지의 재화 가 일어나고 세상은 참혹하게 되었도다. 그러므로 내가 천지의 도수를 정리하고 신명을 조화하여 만고의 원한을 풀고 상생(相 生)의 도로 후천의 선경을 세워서 세계의 민생을 건지려 하노 라. 무릇 크고 작은 일을 가리지 않고 신도로부터 원을 풀어야 하느니라. 먼저 도수를 굳건히 하여 조화하면 그것이 기틀이 되 
대순사상에 있어서 종교다원주의 패러다임의 가능성에 대한 연구 / 김승철| 15

어 인사가 저절로 이룩될 것이니라. 이것이 곧 삼계공사(三界公 事)이니라.” (『전경』, 공사 1장 3절)23)

존재간의 대립과 갈등, 그리고 그로부터 비롯되는 원한을 풀고[解 冤] 서로가 서로를 살리는[相生] 길을 찾아 인간의 존엄성이 담보되는 시대, 그러한 시대는 천존시대(天尊時代)와 지존시대(地尊時代)를 지나 제 삼의 시대로서의 인존시대(人尊時代)의 도래에서 가능해진다. 사람 이 가장 중요하게 여겨지는 인존시대의 원리로서의 '상생'의 원리는 곧 그의 궁극적 실재관과 인간관에 반영되어 있으며, 당연히 그가 태어나 고 자란 아시아의 전통적 종교에 대한 이해에도 반영되어 있다. 그러 므로 ‘상생'이란 개념 속에는 “만물의 존재방식과 윤리적 실천의 개념” 이 포함되어 있다. 즉 '상생'이란 개념 속에선 만물이 존재하는 방식에 대한 이해로서의 존재론과, 그에 합당한 인간의 존재방식으로서의 윤 리가 구분될 수 없는 방식으로 혼재하는 것이다. 따라서 '상생'이란 타 자를 자신의 존재를 위한 필요성 내지 유용성이라는 차원에서 이해한 다든지, 자아와 타자의 차이 그 자체를 없애버리려는 것을 의미하지 않는다. 오히려 하나의 존재자는 자신과는 다른 타자의 존재자로 말미 암아 자신의 존재의 근거를 찾을 수 있다고 하는 적극적인 의미로 해 석되어야 한다. 즉 “서로 반대되는 관계는 상호 성취로서 화해되고, 따 라서 적극적인 조우(遭遇)와 상대적인 작용을 요구하는 것이다.”24)

그런데 본 소고에서 우리들이 관심을 가지는 것은, 이러한 '상생'의 원리가 대순사상의 타종교 이해와는 어떠한 관계를 가지며, '상생'의 원리가 타종교 이해에 어떻게 반영되어 있는가 하는 점이다. 왜냐하면 “서로 반대되는 관계는 상호 성취로서 화해되고, 따라서 적극적인 조 우와 상대적인 작용을 요구하는 것”으로서의 “상생'이야말로, 종교간 의 대화나 종교다원주의를 위한 핵심적인 사항이라고 여겨지기 때문

23) 앞으로『전경(典經)』으로부터의 인용은 대순진리회 교무부가 편찬한 『전경』(대순 진리회 출판부, 1989)을 이용하여 그 해당되는 페이지를 본문 중에 직접 기입하겠다. 24) 이경원, 앞의 책, p.82. 
이다. 이러한 관점에서 주목되는 것은 『전경』에 기록되어 있는 다음과 같은 구절들이다.

“상제께서 정유(丁西)년에 다시 정 남기(鄭南基)의 집에 글방 을 차리고 아우 영학(永學)과 형렬(亨烈)의 아들 찬문(贊文)과 그 이웃 서동들을 가르치셨도다. 이때에 유불선음양참위(儒佛仙 陰陽械緯)를 통독하시고 이것이 천하를 광구함에 한 도움이 되 리라 생각하시고 얼마 동안 글방을 계속하시다가 인심과 속정 을 살피고자 주유의 길을 떠나셨도다." (『전경』, 행록 2장 1절)

“또 어느 날 상제께서 말씀하시기를「선도(仙道)와 불도(佛 道)와 유도(需道)와 서도(西道)는 세계 각 족속의 문화의 바탕이 되었나니, 이제 최수운(崔水雲)을 선도의 종장(宗長)으로, 진묵 (震默)을 불교의 종장으로, 주회암(朱晦庵)을 유교의 종장으로, 이마두(利瑪竇)를 서도의 종장으로 각각 세우노라 고 하셨도다." (『전경』, 교운 1장 65절)

“「서양인 이마두(利馬寶)가 동양에 와서 지상 천국을 세우려 하였으되 오랫동안 뿌리를 박은 유교의 폐습으로 쉅사리 개혁 할 수 없어 그 뜻을 이루지 못하였도다. 다만 천상과 지하의 경 계를 개방하여 제각기의 지역을 굳게 지켜 서로 넘나들지 못하 던 신명을 서로 왕래케 하고 그가 사후에 동양의 문명신(文明 神)을 거느리고 서양에 가서 문운(文運)을 열었느니라. 이로부터 지하신은 천상의 모든 묘법을 본받아 인세에 그것을 베풀었노 라. 서양의 모든 문물은 천국의 모형을 본뜬 것이라」 이르시고 「그 문명은 물질에 치우쳐서 도리어 인류의 교만을 조장하고 마침내 천리를 흔들고 자연을 정복하려는 데서 모든 죄악을 끓 임없이 저질러 신도의 권위를 떨어뜨렸으므로 천도와 인사의 상도가 어겨지고 삼계가 혼란하여 도의 근원이 끊어지게 되니 원시의 모든 신성과 불과 보살이 회집하여 인류와 신명계의 이 겁액을 구천에 하소연하므로 내가 서양(西洋) 대법국(大法國) 천계탑(天啓塔)에 내려와 천하를 대순(大巡)하다가 이 동토(東 土)에 그쳐 모악산 금산사(母岳山金山寺) 삼층전(三層殿) 미륵금 불(㵐勒金佛)에 이르러 三十년을 지내다가 최 제우(崔濟愚)에게 제세대도(濟世大道)를 계시하였으되 제우가 능히 유교의 전헌을 
대순사상에 있어서 종교다원주의 패러다임의 가능성에 대한 연구 / 김승철| 17

넘어 대도의 참뜻을 밝히지 못하므로 갑자(甲子)년에 드디어 천 명과 신교(神敉)를 거두고 신미(辛未)년에 강세하였노라」고 말 씀하셨도다.” (『전경』, 교운 1장 9절)

상기의 구절에서 알 수 있듯이, 증산에게 있어서 유, 불, 선, 그리고 서학은 사람들을 가르치는데 있어서 유용한 방편(方便)이며, 시대의 요청에 의해서 각각 등장한 진리의 한 모습들이다. “선도(仙道)와 불 도(佛道)와 유도(儒道)와 서도(西道)는 세계 각 족속의 문화의 바탕이 되었다.”는 표현이 이렇게 해석될 수 있을 것이다. 그러나 동시에 위 의 구절에서는 증산이 자신의 종교적 자각과 실천이 이러한 다양한 종교적 시도들보다 우위에 서 있음을 주장하는 내용도 포함되어 있다. 종교다원주의를 위한 아시아적 패러다임을 구축하려는 우리들에게 이 러한 사실은 무엇을 의미하는 것일까?

먼저 위에서 인용해 본 일련의 구절들은 대순사상의 연원이 되는 증산의 종교적 자각이 이른바 '삼교(三爽)의 원융(圓融)'이라는 사상과 어떠한 방식으로든지 연결되면서 기술되고 있음을 가리키는 바, '삼교 의 원융' 내지 '일치(一致)'라는 사상은 전통적인 한국의 종교성을 바 탕으로 새로운 종교적 이해를 전개하고자 할 때 그 근본이 되고 있다. 예를 들어서 신학자 유동식은 한국의 고유종교와의 대화를 통해서 빚 어낸 자신의 '풍류신학'(風流神學)의 사상적 연원으로서 통일신라시대 의 최치원(崔致遠, 857-?)의 말을 인용한다. 삼국사기에 기록되어 있 는 최치원의 말은 다음과 같다. "우리나라에 현묘(玄妙)한 도(道: 靈性) 가 있다. 이것을 풍류(風流)라고 한다. $\cdots$ 이는 실로 삼교(三敉: 儒佛仙) 를 포함[今今口呚]하고 있는 것이며, 뭇 사람들에게 접해서는 그들을 교 화(㸚化)한다.”25) 유동식은 이어서 다음과 같이 말한다.

“풍류도는 실로 삼교(三呚)를 포함한 것이라 했다. 유교의 본 질을 극기복례(克已復禮)에서 찾고, 불교의 본질은 귀일심원(歸

25) 유동식, 『풍류신학으로의 여로』(서울: 전망사, 1988), p.19. 
一心源)에서, 도교의 본질을 무위자연(無爲自然)에서 각각 찾을 수 있는 것이라면, 이 세 종교는 다 같이 자기를 극복하고 하늘 이 내린 천성(天性)으로 돌아가기를 가르치고 있다. 천성이란 하느님이 주신 본성이요, 하느님의 마음이다. 그러므로 하느님 과 하나가 되는 풍류도야말로 삼교(三敉)를 다 포함한 것이라 했다.”26)

나아가서 유동식은 풍류도가 한국인 전체의 보편적 종교성이라고 말한다.

"풍류도란 어떤 한 종교에 대한 명칭이 아니다. 각종 종교를 받아들이고 이것을 전개시키는 종교 문화의 장(場)이며, 정신적 원리가 되는 영성(靈性)이다. 풍류도는 또한 고대에 있었던 영 성만을 말하는 것이 아니다. 이것은 한국문화 전체의 기초가 되 어온 민족적 영성이다. 곧 현대 한국인의 의식 속에서도 살아있 는 영성이며, 한국 문화의 기초 이념을 이루고 있는 것이다. 따 라서 풍류도는 한국인에게는 불변의 정신적 원리이여, 구조적인 것이다. 개인으로서의 자각 여하를 막론하고 한국인에게는 보편 적인 것이며 일상적인 것이다.”27)

이처럼 유교와 불교와 도교의 세 가지 교[三敉]를 하나의 통일적 유기관계로서 보는 입장을 “한국문화 전체의 기초가 되어온 민족적 영성”, 곧 한국인의 보편적 종교성으로서 평가될 수 있다고 한다면, 증산이 삼법(三法)을 비판적으로 수용하면서 자신의 독특한 종교성을 제시할 수 있었다는 역사적 사실도 위와 같은 포괄적 종교성으로 설 명될 수 있을 것이다.28)

그러나 여기에서 우리들이 보다 더 주목하려는 것은 조선후기의 종 교적 상황의 특징으로서 거론되는 동양전래의 삼교(三敉)전통을 대순

26) 같은 책, pp.19-20.

27) 같은 책, p.20.

28) 박마리아, 「포스트모던사회와 대순진리회: 다원성의 구현을 중심으로, 『신종교연 구』 20 (2009), p.33. 
대순사상에 있어서 종교다원주의 패러다임의 가능성에 대한 연구 / 김승철| 19

사상이 어떻게 창조적으로 이해하였는가 하는 문제이다. 당시의 지배 적인 종교가 일반 기층민들의 종교적 요구나 서구로부터의 문화적 충 격에 응답하지 못하였다는 사실은, 당시의 민중들의 종교적 각성에서 비롯된 대순사상이 유교, 불교, 도교로 대표되는 삼교를 비판적으로 극복하였음을 짐작케 해주기 때문이다.29) “선불유 삼법은 고대로부터 한국 종교와 사상의 중추적 뼈대를 이루었으나, 증산에 의해 단일적 의미가 해체되고 재해석됨으로써 통합과 개혁의 의미를 동시에 현시 하고 있다.”30)는 지적 그대로이다.

그런데 이와 관련하여 대순진리회의 종교학자 이경원의 다음과 같 은 논술은 종교다원주의를 둘러싼 우리들의 논의에 있어서 중요한 토 론점을 제기한다고 할 수 있다.31) 그는 구한말의 신종교의 특성을 논 하는 "구한말의 신종교가 제각각 하나의 전통종교를 주체로 하여 타 종교를 포섭한 것이라는 주장”이 있음을 거론하면서, “대체로 신종교 연구자마다 공감하는 것이 있다면 삼교의 합일이 그야말로 단순합일 또는 종교적 혼합주의로 인식되어서는 안 된다는 점이다.”라고 주장한 다. 하지만 그에 의하면 종교적 혼합주의(syncretism)는 "하나의 종교 가 자리 잡기 이전에 과도기적 단계 또는 과정에 속하며, 다분히 어떤 현상을 얕보는 판단으로 사용된다.”고 본다. 따라서 신종교가 삼교를 “삼합(三合)하든, 통합(統合)하든 그 합을 넘어서는 어떤 교리적 실체 를 규명하는 것이 무엇보다도 중요하다.”32)고 본다. 그런데 이러한 주장은 보다 세밀한 논구를 요하는 것임에 틀림없다.

우선 혼합주의가 “하나의 종교가 자리 잡기 이전에 과도기적 단계 또는 과정에 속한다."는 주장은, 혼합주의를 동양적 종교심의 구조적 특징으로서 파악하려는 시도로부터 본다면 다소 피상적이라고 하지 않을 수 없다. 흔히들 한국과 일본을 비롯한 아시아의 종교적 문화적

29) 이경원, 앞의 책, p.320.

30) 박마리아, 앞의 글, p.28.

31) 이하는 이경원, 앞의 책, p.361.

32) 같은 책, pp.361-362. 
상황은 다양한 종교의 공존에 의한 다양성을 그 특질로 하고 있다고 말해진다. 일본의 종교의 특색으로써 - 실은 아시아적 신앙 양태 일반 이 지닌 특성이라고도 할 수 있겠지만- ‘중층신앙(重層信仰)'이 빈번 하게 거론되는 것을 상기해 보면 금방 알 수 있다. '신불(神佛)의 교 착', '신종교(新宗敎)', '신신종교(新新宗敉)' 등등, 일본의 종교적 현실 을 묘사하는 용어 및 조어도, 이러한 상황이 만들어 낸 산물일 것이 다. '중층신앙'이란, 일본의 신학자 후루야가 지적하고 있는 것처럼, “동시에 세 개 이상의 복수의 종교의 신자"가 되는 것을 가능하게 하 는 일본적 종교관의 독특성을 가리키는 용어이다. 이것은, 종교를 “사 회적 기능 내지 습속”으로 파악하는 태도로서, “불교라고 하면 장례 식, 신도라고 하면 결혼식이라는 식의 종교의 분업화”는 이러한 정신 풍토에서 가능할 것이다.33) 여기서 말하는 '중층신앙'이야말로 '혼합 주의'의 본질이라고 할 수 있다면, 혼합주의는 결코 과도기적인 단계 이거나 폄하되어야 할 어떤 것이 아니다. 그것은, 앞서 유동식의 표현 을 빌린다면, “한국문화 전체의 기초가 되어 온 민족적 영성”이라고 할 수 있는 것이다.

일본의 독특한 가톨릭 신앙으로서의 기리시단(切支丹)을 연구하는 에비사와도 “기독교의 일본 전래는, 신(神), 유(儒), 불(佛)이 각각 특 질을 가지고 있으면서도 삼교일치(三呚一致)적으로 공존하는 종교 사 회와의 접촉이라는 점에 있어서, 세계 종교 사상에 유례를 찾아보기 힘들다.”34)고 지적하고 있다. 이러한 현상 역시 후루야가 말하는 일 본인의 - 그리고 보다 넓은 의미에서는 아시아인에게 공통되는 - 종교 성의 자연스러운 발로일 것이다. 이러한 사정은, 에비사와가 일본의 기리시단 시대의 특징으로써 언급했던 다음과 같은 말에 의해서도 뒷 받침된다.

33）古屋安雄, 『現代キリストと将来』(東京: 新地書房, 1984), pp.183-184.

34）海老沢有道, 『日本キリシタン史』（東京：塙選書, 1966), p.178. 
대순사상에 있어서 종교다원주의 패러다임의 가능성에 대한 연구 / 김승철| 21

“기독교가 그리스 로마의 이교 사회를 풍미한 이후는 언제나 미개 사회에로의 포교였는데 반하여, 아시아라고 하는 특수하게 발달한 종교 문화권에로의 포교는 달리 예를 찾아보기 힘든 현 상으로서, 신도(神道)라고 하는 강한 민족 신앙, 불교라고 하는 이질(異質)의 철학, 유교라고 하는 봉건적 가치 체계를 가지는 종교 혹은 세계관이 존재하고, 게다가 그것이 공존하는 특수한 사회와 기독교 내지 유럽의 사상-문화와의 접촉이라는 의미에 서, 세계에 달리 유례를 찾기 힘든 사례로서, 이는 세계사적 과 제임과 동시에 일본 사상사적으로도 중요하고도 흥미 있는 과 제라고 해야 할 것이다.”35)

이경원도 한국 신종교의 특징의 하나로서 “궁극적 실재의 양면성” 을 논하는 자리에서 종교학자 반델레프의 생각에 의존하면서 말하고 있듯이, "모든 종교는 그자체로 독존하는 체계가 아니라, 살아있고, 자라며, 사멸하는 존재들로서 다른 종교들과 계속되는 교류를 통해서 만 생존할 수 있다. 우리는 이것을 종교의 역동성이라 부르고 그것으 로써 우선 종교혼합(syncretism)을 의미한다.”36) 이런 점에서 삼교의 '융합'이나 '통합’이라는 발상은, 그 어원적 정의가 여하한 것이건 간 에, 동양의 종교적 자각 그 자체에 포함되어 있다고 할 수 있으며, 위 에서 살펴 본 바와 같이, 아시아적 종교다원주의의 패러다임을 제공해 줄 가능성을 지닌다고 하지 않을 수 없다. 한국의 전통종교를 다루는 여러 논문들이 공통적으로 지적하고 있듯이, 한국의 종교 사상의 흐름 속에는 삼교회통(三呚會通)의 정신이 맥맥이 흐르고 있다. 우선 통일 신라시대의 최치원(崔致遠, 857-?)의 '삼교병행론'(三呚立立行論), 조선 시대 원천석(元天錫, 1330-1401)의 '삼교일리론'(三呚一理論), 함허기 화(涵虛已和, 1376-1433)와 휴정(休靜, 1520-1604), 그리고 휴정의 법통을 이은 무경자수(無竟子秀, 1664-1737)의 '삼교회통론'(三呚會 通論)을 꼽을 수 있으며, 조선조 말기에 동학을 일으킨 수운(水雲) 최

35) 같은 책, pp.14-15.

36) 이경원, 앞의 책, p.55. (주78) 
제우(崔濟愚, 1824-1864)와 증산의 '삼교론'(三㸚論), 그리고 역시 한 국의 신종교로서 등장한 원불교의 '삼교원융론'(三敉圓融論) 등을 거론 할 수 있을 것이다.37) 또한 우리들은 한국 불교의 큰 흐름을 형성한 보조국사(普照國師) 지눌(知訥, 1158-1210)이 스스로 선사(禪師)이면 서도 교학(㸚學)과 염불문 등, 불교 내의 다양한 전통을 통합(統合)하 면서 회통불교를 지향하였으며, 따라서 그의 불교사상이 “아시아에서 가장 에큐메니칼적인 전통”38)이라고 평가된다는 점도, 이러한 유연하 고 포괄적인 종교이해와 무관치 않을 것이다.

\section{$\mathrm{IV}$. 대순사상의 종교다원주의}

이상과 같은 한국의 전통종교들의 종교이해에 비추어 볼 때, 한국 의 신종교로서의 대순사상이 노정하는 종교적 포괄정신은 그 자체가 동양의 종교적 자각의 자연스러운 발로라고 보아야 할 것이다. "한국 신종교는 회통적 다원주의(synthetic pluralism)의 입장을 견지한다." 는 박광수의 지적은 대순사상에도 그대로 적용될 수 있다. 이런 점에 서 『전경』에 기록되어 있는 다음의 구절은 대순사상이 종교적 다원성 을 실천적인 차원에서 이해하고 있음을 분명하게 제시한다.

"옛적에는 판이 좁고 일이 간단하므로 한가지만 써도 능히 광란을 바로 잡을 수 있었으되 오늘날은 동서가 교류하여 판이 넓어지고 일이 복잡하여져서 모든 법을 합하여 쓰지 않고는 혼 란을 능히 바로 잡지 못하리라.” (『전경』, 예시 73절)

37) 이진재, 「원불교 사상에 나타난 유·불·선 삼교회통에 관한 소고」, 『원불교학연구』 17 (1987).

38) Robert E. Buswell, Jr., "Introduction: The Life and Thoughts of Chinul", The Korean Approach to Zen: The Collected Works of Chinul, tr. by Robert E. Buswell, Jr. (Honolulu: University of Hawaii Press, 1983), p.1. 
대순사상에 있어서 종교다원주의 패러다임의 가능성에 대한 연구 / 김승철| 23

그렿다면 대순사상의 소의경전(所依經典)으로서의『전경』은 “제종 교의 경전에 대한 통전적(統全的, Holistic) 성격을 지닌다.” 39 )고 할 수 있다. 『전경』행록 5장 38절에서 “서쪽의 대 성인이 서학을 설하 고, 동쪽의 대성인이 동학을 말하는 것은 모두 백성을 교화(㸚化)하기 위함이었다(西有大聖人日西學 東有大聖人日東學 都是敉民化民).”고 하 여 동서양의 종교들을 모두 백성을 교화하는 가르침으로 보았는데, 이 는 각 종교들이 비록 “발생한 지역과 중심인물은 다르지만 모두가 성 (聖)의 가치를 구현하기 위하여 뭇사람들을 교화하는데 목적이 있었 다." ${ }^{40)}$ 고 인정한 것이다.

그렇다면 유교와 불교와 선도는 각각 어떤 기능을 하여왔는가? 『전경』 에 의하면 불교는 형체(形體)에, 선교는 조화(造化)에 그리고 유교는 범절 (凡節)에서 핵심가치를 발견한다. "이러한 종교들이 역사에 걸쳐서 단계 별로(子 $\rightarrow$ \#\# $\rightarrow$ 寅) 나타났고 각각 천(天), 지(地), 인(人) 삼재(三才)와 같이 개별적인 가치를 지니면서도 다 같이 허령(虛靈), 지각(知覺), 신명 (神明)으로 묘사되는 인간의 공통된 성스러운 본체를 강조하였다." 41$)$

그런데 대순사상이 삼교가 근본적으로 원융하며, 대중을 구원함에 있어서는 삼교를 방편으로서 널리 사용하여야 하며, 그러면서도 대순 사상이 지닌 독특성을 주장할 수 있다고 보는 그 원리는 무엇인가? 이경원에 의하면 “삼교의 정신을 종합하는 구체적인 원리와 개념”이 『전경』에서 “관왕(远旺)”이라는 표현을 통해서 나타났으며, “여기에 삼교에 관한 규정과 그 초극의 정신이 대순사상의 핵심인 해원상생을 통해 나타나 있다."42)고 말하고 있다. 그리고 "관왕”이라는 개념은 “도솔(兜率)”이라는 개념과 어울리면서 삼교를 포함하면서도 이를 뛰 어 넘어 새로운 의미를 전달하는 대순사상의 특성을 규정하는 원리가

39) 이경원, 『대순진리회의 신앙론』(서울: 문사철, 2012), pp.312-313.

40) 같은 책, p.313.

41) 같은 책, p.314.

42) 같은 책, p.362; 이경원, 「대순사상의 삼교관왕론 연구」, 『신종교연구』 17 (2007), pp.230-277. 
된다.43) “관왕”과 “도솔”이라는 두 개념은 그러므로 대순사상이 이론 적이고 실천적인 의미에서 종교다원주의를 전개해 나갈 수 있는 핵심 개념이 되는 셈이다.

그렇다면 “관왕”과 “도솔”이란 무엇인가? “관왕”이란 다음과 같은 만물의 발전단계에 포함되어 있는 단계로서, 살아있는 생명체가 잉태 되어 태어나고 자라서 성장하지만 “관왕”의 단계를 지나면 쇠락과 멸 절의 길로 들어서게 되는 것에서 비롯된 개념이다. 관왕은 따라서 살 아있는 만물의 발전양상의 정점을 가리킨다.

$$
\begin{aligned}
& \text { 포 }(\text { 胞 }) \rightarrow \text { 태 }(\text { 胎 }) \rightarrow \text { 양 }(\text { 養 }) \rightarrow \text { 생 }(\text { 生 }) \rightarrow \text { 욕 }(\text { 浴 }) \rightarrow \text { 대 }(\text { 帶 }) \rightarrow \text { 관 }(\text { 冠 }) \\
&\rightarrow \text { 왕 }(\text { 旺 }) \rightarrow \text { 쇠 }(\text { 衰 }) \rightarrow \text { 병 病 }) \rightarrow \text { 사 }(\text { 死 }) \rightarrow \text { 장 }(\text { 葬 })
\end{aligned}
$$

그리고『전경』은 “관왕”에 대해서 다음과 같이 설명한다.

“受天地之虛無仙之胞胎 受天地之寂滅佛,之養生 受天地之以詔 儒之浴帶 冠旺 樂率虛無寂滅以詔”44) (『전경』, 교운 1장 66절)

『전경』이 이러한 발전단계를 각각의 종교에 해당시키면서 했던 “受 天地之虛無 仙之胞胎. 受天地之寂滅 佛之養生. 受天地之以詔 儒之浴帶. 冠旺”이라는 구절은 다음과 같이 풀어 이해할 수 있다. “포태”는 무로 부터 유가 나오는 '조화(造化)'의 단계로서 종교적으로는 선도에 해당 한다. “양생”은 무로부터 존재를 받은 생명체가 형체를 갖추어서 세상 에 태어나는 것을 가리키는 말로서 종교적으로는 불교에 해당한다. “욕대”란 “태어난 인간이 다른 사람과 관계를 맺으면서 사회생활을 하기 위한 교육을 받는 단계”로서 이는 예의범절을 가르치는 유교에 해당한다. 이러한 발전단계를 거치면서 성장해 온 생명체는 “관왕”에 이르러 “완전한 인격을 갖춘 성숙한 성인으로서 자신의 지위를 가지

43) 같은 책, p.315.

44) 천지의 허무의 기운을 받은 선도는 포태(胞胎)이고, 천지의 적멸의 기운을 받은 불 도는 양생(養生)이며, 천지의 이조의 기운을 받은 유도는 욕대(浴帶)이다. 관왕(冠旺) 이 허무와 적멸과 이조의 기운을 모두 이끌어간다[喼率]. 
대순사상에 있어서 종교다원주의 패러다임의 가능성에 대한 연구 / 김승철| 25

고 왕성하게 자신의 역할을 다하는 모습을 일컫는다."

이처럼 다(多)로부터 초월적이고 궁극적인 일(一)로 종교는 진화, 발 전하며 그러한 일(一)을 구현한 것이 대순사상이라는 말이다.45)『전경』 이 “관왕”을 언급한 후 “兒率虛無寂滅以詔”라고 부언하고 있는 것은 이 러한 사실을 반복해서 강조함일 것이다. 즉 허무와 적멸과 이조를 감싸 면서[恖] 거느린다[率]는 뜻이다. 다시 말해서 “관왕”의 경지로서의 대 순사상은 선도와 불교와 유교를 거치면서 발전해 온 종교를 “감싸면서 거느린다."는 말이니, 이는 대순사상이 삼교를 통합하면서도 삼교를 능 가하고 초월하는 정점(頂点)에 서 있다는 자기이해인 것이다.

그런데 흥미로운 것은, 실은 이러한 종교이해가 아시아의 신종교에 서 어렵지 않게 찾아 볼 수 있는 현상이라는 점이다. 예를 들어서 일 본의 신종교의 하나인 텐리교(天理呚)는 텐리교와 타종교와의 관계를 “다메의 가르침”(だめの教え)이라는 말로 표현하고 있다. “다메”(駄目) 라고 하는 일본어는 원래는 바둑의 용어로서, 어떤 돌의 주위에 있는 빈 점을 가리킨다. 이 빈점을 모두 메우면 그 돌을 나의 것으로 취할 수 있다. 그래서 “다메를 둔다.”(駄目を押す)라고 하면 거의 이긴 승부 에 더 확정적으로 승부수를 두어서 승리를 확실하게 한다는 의미를 갖는다. 즉 전체를 완성한다는 의미에서 '최종적', '궁극적'이라는 뜻으 로 전화(轉化)된 것이다. 『텐리교 교전』(天理呚呚典)은 세계와 인간의 근원을 밝히는 창세담(創世譚)이라고 할 수 있는 제 3장의『모토노리』 (元の理)에서 이에 대해서 다음과 같이 말하고 있다.

"열개의 것이 있다면, 아홉 개까지는 가르쳐졌다. 아직 밝혀 지지 않은 마지막 한 점, 즉 근본이 되시는 신(모토노가미, 元の 親)을 알려주시고, 인류에게 어버이 되시는 신(오야가미, 親种) 의 자녀라는 깨달음을 주시었고, 한 형제 자매로서 화목할 것을 촉구하시고, 어버이와 자녀가 이 세상을 즐겁게 살아갈 수 있는 세계로 바꾸도록 하시기 위해서이다.'

45) 같은 책, p.316. (주27) 
그러면서『텐리교 교전』은 텐리교의 교조(呚祖)가 남긴 “오후데사 키”(お子でさき)로부터 다음과 같은 말들을 인용하고 있다. “오후데사 키”는 천리교의 교조인 나카야마 미키(中山みき, 1798-1887)가 남긴 '친필'로서, 한자는 일체 없고, 모두 히라가나(尔仮名)로만 쓰여 있다. 이는 천리교가 당시의 서민 대중을 향한 종교로서 태동하였음을 말해 주고 있다.

“이 세상을 만든 신의 일이라면

온 세상 사람들은 모두 신의 자녀

신에게는 모두가 그의 자녀

세상 사람들은 신을 어버이로 생각해야 한다.

온 세상 사람들은 모두 한 형제이다.

타인이라고 할 수 있는 사람은 없는 것이다."46)

그러므로 텐리교의 자기이해에 의하면 천리교는 인류에게 밝혀졌던 종교적 진리의 궁극점이다. 이는 지금까지 기독교가 타종교에 대해서 지니고 있던 발상으로서의 포괄주의와 유사하다고 할 수 있는데, 이 점에 대해서 천리교학자 히가시바바는 기독교의 타종교 이해와 텐리 교의 타종교 이해를 다음과 같이 비교해서 말하고 있다. "기독교의 “종교의 신학"에서 이미 요해되어 있는 것과 같은 의미에서 텐리교에 서 이루어지는 논의에 있어서도, 타종교에 대한 포괄적 시점과 배타적 시점 사이에 본질적인 차이는 없다. 기독교의 예에서도 지적한 것처 럼, 타종교의 가르침을 스스로의 전체 계시에 있어서의 부분적 성취로 간주하는 것은, 스스로의 궁극성, 절대성의 주장을 버리고 스스로를 진리에 도달하는 과정의 하나로서 상대화하는 것은 아니다. 포괄적 계 시론의 경우도, 『마지막 일점』이라는 개념을 매개로 해서 타종교의 가 르침을 교조의 계시와 관련지은 시점에서, 벌써 타종교의 가르침에는

46）天理敎敎會本部 編，『天理敎呚典』(天理: 天理敎道友社，2012，83판), pp.33-35 참조; 島田勝巳，「区天理教学』の生成と展開: 媒介としての宗教諸学の意義を女ぐって」, 『天理教学研究 43 (2009), p.136. 
당사자의 이해를 떠난 의의가 덧붙여진 것이기 때문이다. 그것은 어디 까지나 텐리교의 절대성에 근거해서 구축된 종교관이다." ${ }^{47)}$

그렇다고 한다면 대순사상이 자신의 종교를 “관왕”과 “도솔”이라는 개념으로 집약하면서 타종교와의 관계를 설정한 것은 앞의 제 2 장에서 살펴보았던 것처럼, 이른바 ‘포괄주의적'이면서도 ‘통일적 다원주의’를 지향한다고 할 수 있지 않을까? 대순사상이 삼교의 ‘창조적 완성’이라 는 아래의 해석은 이와 같이 독해되어도 무방하지 않을까?

“요약하면 관왕은 곧 포태와 양생 그리고 욕대를 거쳐 성숙 된 창조적 완성의 경지이다. 그 종교적 경지를 설명하면 선(仙) 불(佛) 유(儒)를 모두 포함하고 이를 종합적으로 거느린다는 것 이다. 말하자면 대순진리회의 신앙의 경전에서 다루는 종교적 이념과 그 실천적 내용은 선(仙)의 조화(造化)와 불(佛)의 형체 (形體), 유(儒)의 범절(凡節)이 서로 조화(調和)를 이루는 것을 나타낸다. 이 세 가지가 정족(鼎足)이 되어 새로운 차원의 진리 를 떠받치고 있다는 점에서 대순진리는 통전적 성격을 지니며 아울러『전경』은 그 특징을 담고 있는 유일한 신앙의 경전이라 고 하겠다." ${ }^{818)}$

종교학자 장병길은 만물의 발전원리를 규정한 “관왕”이라는 개념을 다음과 같이 풀이하는데, 여기서 우리들은 “관왕”이 삼교를 포섭하면 서도 특히 도교적인 이해에 기울어져 있음을 재확인하게 된다.

“양자의 괘를 조람(照覽)한다면, 하도는 우주의 창조를 설계 한 것인데, 그 설계대로 조화되지 않아서 낙서에서 볼 수 있는 바와 같이 우주만상은 난양난음(亂陽亂陰)에 의해서 이그러졌다.

47）東馬場郁生, 「天理教の諸宗教の教学への試み, 『天理大学学報』56-1 (2004), p.95. 텐 리교는 이상에서 논구된 타종교관에 근거해서 기독교와의 대화에도 적극적으로 임하고 있다. 그 결과의 하나로서 2002년에 로마의 그레고리안대학과의 공동개최로 기독교와의 대화를 시도하였다. 다음은 그 결과물의 하나이다. 『天理国際シンポジウ ・グレゴリアン大学共催 天理教とキリス卜教の対話 II：教育・家族・宗教』（天理：天理大 学出版部, 2005).

48) 이경원, 『대순진리회의 신앙론』, pp.317-318. 
따라서 불식난세(不息亂世)하고 그 열국(列國)이 난립하고 귀천 이 극심하고 빈부의 차가 우심하여 인심화순(人心和淳)을 찾아 볼 길이 없어졌다. 이상의 하도(河圖)와 낙서(洛書)를 『전경』은 체용(體用)으로 보고『현무경』은 하도를 정자와 난자에 의한 포 태(胞胎), 즉 만물생성하는 시점으로 보고, 낙서를 그 포태에 의 해서 생성할 수 있는 양생(養生)으로 보고, 또 전자를 성부(聖 父), 후자를 성자(聖子)로 보고, 이것을 모두 선천(先天)의 것으 로 보았다. 그리고 양괘를 종교에 적용하여 선교(仙敎)를 포태, 불교를 양생으로 보았다. 이와 같이 보면 괘나 괘수(度數)의 바 로잡음이 있어야 하고 그것을 바로 잡는 어떤 초인간적이 인격 자가 전제되어야 함을 쉽게 이해할 수 있다. 그런 전제에서『전 경』은 상제가 강세하기에 앞서 수십년 동안 탁운(托雲)하시다가 드디어 외재화(外在化)하여 제삼적인 도수를 조화정(造化定)하 여 전 이자의 괘수를 관왕(冠旺)하였고, 포태하고 양생하는 것 의 매듭을 지었던 것이다."49)

“관왕”은 그러므로 앞의 두 시대, 곧 하늘과 땅이 중요시되던 시대 를 지나서 하늘과 땅 사이에 존재하는 인간을 가장 존귀하게 여기는 인존시대(人尊時代)에 필요한 이법이 된다. 하늘과 땅의 대립을 지나, 양자를 인간을 중심으로 포괄하는 원리가 곧 “관왕”인 것이니, 이는 이른바 근대적인 자율적인 인간의 일면성을 인간에 내재하는 원리에 의해서 다시 한 번 극복하고자 하는 원리가 된다.50)

관왕의 원리가 지배하는 인존시대는 각자의 깨달음의 노력이 응보 를 얻는 시대이다. 마음을 닦는 것이 인존시대에 와서 특히 중요한 이 유가 여기에 있다. “천존과 지존보타 인존이 크니 이제는 인존시대라. 마음을 부지런히 하라.”(『전경』 교법 2장 56절) 왜냐하면 “마음”이란 “천지의 중앙”이며, “동서남북 사방과 몸이 모두 마음에 의존(天地之 中央心也 故東西南北身依於心)"(『전경』교운 1장 66절)하기 때문이다. 이러한 마음을 닦는데 있어서 유, 불, 선은 각각의 인연에 따라 사람들

49) 한국종교문화연구소 엮음, 『장병길 교수 논집: 한국 종교와 종교학』(서울: 청년사, 2003), p.634.

50) 같은 책, p.603. 
대순사상에 있어서 종교다원주의 패러다임의 가능성에 대한 연구 / 김승철| 29

을 돕는다. 거기에는 어느 하나의 종교가 깨달음을 독점하는 일은 있 을 수 없다. 그러한 독점의식은 '상생'의 시대에는 어울리지 않을 것이 다. "내가 도통줄을 대두목에게 보내리라. 도통하는 방법만 일러주면 되려니와, 도통될 때에는 유불선의 도통신들이 모두 모여 각자가 심신 으로 닦은 바에 따라 도에 통하게 하느니라. 그러므로 어찌 내가 홀로 도통을 맡아 행하리오.”라고 상제께서 말씀하셨도다.(『전경』 교운 1장 41절)

“이제 해원시대를 맞이하였으니 사람도 명색이 없던 사람이 기세를 얻고 땅도 버림을 받던 땅에 기운이 돌아오리라. 후천에 서는 그 닦은 바에 따라 여인도 공덕이 서게 되리니 이것으로 써 예부터 내려오는 남존여비의 관습은 무너지리라." (『전경』, 교법 1장 67-68절)

“천지공사”(天地公事)란 “천지를 개벽하고 새롭게 배포를 꾸민다.” 고 하는 증산의 사상인 바, 천지개벽을 천지가 운행하는 길[운로]을 회전시키는 작업이고 새로운 배포는 도수(괘)를 정하는 작업이다. 증 산이 “천지의 도수를 정리한다.”(『전경』 공사 1 장 3 절)고 한 것은 이 를 가리킨 것이다. 선천시대란 공간[宇]을 중심으로 한 시대로서 인류 가 지방의 구별로 인해서, 또 부족이나 종족으로 갈라져서 서로 상극 (相克)하면서 살던 시대이다. 이러한 공간 중심의 세계를 시간[宙]을 중심으로 하는 하나의 세계로 바꾸는 작업이 천지공사이다.

또한 선천시대를 종교적으로 구분해 보면 동쪽에서는 삼교의 원리 인 포태, 양생, 욕대에 의해서 유지되었는데, 각각의 종교는 마치 인 간의 성장단계에 비유될 수 있다. 즉 동쪽에서는 탄생하여 성장할 때 까지는 선도의 지혜에 의해서 인도되었고, 서쪽에서는 기독교의 과학 으로 유지되었다. 그러므로 동과 서가 서로 상극한 것이고, 선천시대 에는 상극이 오히려 합당한 것으로 여겨진다. 개인과 사물이 대립과 갈등의 변증법적 발전단계를 거쳐서 성장하듯이, 만물은 선천시대에는 
이러한 생물학적 성장과정을 거치면서 성장한다. 그러나 이제 우주가 완성되는 시기에 이르러서는 상극의 법칙은 상생의 법칙으로 대체된 다. 이 상생의 법칙이 유, 불, 선과 서도(西道) 모두를 도솔(皃率)한 관왕의 법이니, 이것이 곧 진법이다.51)

대순사상이 대립되는 것의 통합을 지향한다는 사실은 대순사상이 궁극적 실재의 인격적인 측면과 초인격적 측면 사이의 대립을 종합하 려 한다는 점에서도 드러난다. 즉 궁극적 실재를 인격적 존재로 파악 하는 관점과 비인격적 원리로서 이해하는 측면을 동시에 지닌다. 주지 하다시피 알버트 슈바이쩌(Albert Schweitzer, 1875-1965)나 에른스 트 트뢸치가 동양의 종교에 대한 기독교의 우월성을 논하면서 그 근 거로서 들었던 것이 궁극적 실재의 인격성과 비인격성에 대한 견해였 다. 슈바이쩌와 트뢸치는 신을 인격적 존재로서 이해하는 윤리적인 종 교로서의 기독교와 우주의 궁극적인 원리에 대한 자각을 추구하는 동 양의 존재론적인 종교 사이에는 우월의 차이가 있다고 보았다. 물론 그들 서구의 신학자에게 있어서 이른바 '윤리적 종교'가 그들이 이해 하는 동양의 종교로서의 ‘존재론적 종교'보다 우위에 있음은 자명한 일이었다.

이경원은 증산이 스스로를 인격신의 현현으로서 이해하고 있다는 점에서 유신론적 성격을 띤다고 보면서도 인격적인 상제 이외에도 원 리적인 성격을 띠는 천리나 천도라는 개념도 궁극적인 실재를 이해하 는 범주로서 사용된다는 점을 들어서, 증산의 종교적 자각 속에는 궁 극적 실재를 인격적으로 파악하는 경향과 비인격적으로 보는 경향이 공존한다고 보았다. 앞에서도 인용하였듯이, 증산이 강세한 것은 “천 도와 인사의 상도”가 어겨지는 것을 보고 이를 바로잡고 세상을 구원 하기 위함이었다. 그러므로 "현대종단이 대순진리회에서 유신론적 신 앙 요소를 저변으로 지니고 있으면서도 개인적인 단전수련과 우주역 학적인 이론을 교화 속에서 활용하고 있는 현상은 이와 같은 특징의

51) 같은 책, p.459. 
대순사상에 있어서 종교다원주의 패러다임의 가능성에 대한 연구 / 김승철| 31

하나로 주목될 수 있을 것 같다.”고 결론짓는다. ${ }^{52)}$

“증산의 '천하’에 대한 종교적 문제의식과 방법적인 귀결은 기성종 교에 대한 이해와 극복을 통해 그 새로운 진리의 선언으로 나아가는 데 특징이 있다.”53) 그런데 한국의 신종교에서는 이러한 이원론적 이 해가 지양되어 “인격적인 실재의 측면과 원리 규범적인 실재의 양면 성을 고루 지니고 있다.” 이러한 양면성은 종교의 혼합주의적 경향에 의해서도 설명될 수 있지만, 모든 종교에서 역사적으로 경험하는 그런 특징과는 사뭇 다르다고 보아야 한다. 즉 한국의 신종교는 그 발생 시 기에 이미 동, 서 문화의 충돌을 경험하였고, 그 주된 문명의 축이 종 교로 대변되는 만큼, 그 양자를 초극하는 이념이라야만이 새 시대를 이끌어 나갈 수 있기 때문이다.”54)

\section{$\mathrm{V}$. 결론을 대신하여: \\ 대순사상과 종교다원주의 논의를 위한 과제}

지금까지 우리는 종교다원주의를 둘러싼 기독교의 논의를 살펴보았 고, 한국의 신종교가 종교다원주의를 위한 패러다임을 제공해 줄 수 있는지에 대해서 논구해 보았다. 기독교를 중심으로 한 종교다원주의 의 논의는 종교간의 대화를 통해서 그 한계와 의미가 극복, 지양되어 야 한다는 사실을 지적하였다. 그렇다면 같은 논리에서 한국의 신종교 가 종교다원주의의 패러다임의 창출이라는 목표에 응답하기 위한 과 제를 논하는 것이 균형 잡힌 논술이라고 할 것이다.

한국의 신종교가 조선말기, 즉 국제적인 정치지형의 변화와 그러한

52) 이경원, 『한국 신종교와 대순사상』, pp.57-58.

53) 같은 책, p.365.

54) 같은 책, p.55. 
변화가 여과 없이 국내에 영향을 미치고 있던 격변기에 민족적인 각 성의 흐름을 타고 태동한 민족종교의 성격을 띤다는 사실은, 신종교가 태생적으로 외부에 저항- 배타적이고 민족중심적인 경향을 띨 가능성 을 지니고 있음을 간과해서는 안 된다. 대순사상을 논함에 있어서 이 러한 사회적 맥락을 함께 고려하여야 한다는 사실은 대순사상을 바탕 으로 종교다원주의의 언설을 위한 새로운 패러다임의 추구가능성을 논하는 우리들로서도 기억하지 않으면 안 될 중요한 요소이다. 더욱이 당시의 신종교가 서구의 기독교의 유입에 대한 전통적 종교로부터의 응답의 의미를 뚜렷이 함축하고 있다는 사실은, 대순사상을 포함한 신 종교가 - 서구의 기독교를 포함한-이른바 기존의 종교에 대해서 단 순히 포용적이고 포괄적인 입장을 지닐 수 없었던 역사적 정황을 말 해준다고 해석될 수 있는 것이다.

더욱이 우리들이 기억해야 할 것은, 앞 절에서의 논의에서도 암시 되었듯이, 종교적 다원성 내지는 그러한 다원성에 대한 이론적 고찰로 서의 종교다원주의에 대한 의식은 지극히 현대적인 것이며, 따라서 역 사적 배경과 더불어 등장한 것이라는 사실이다. 흔히들 서구의 유일신 론적 종교는 배타적이고, 동양의 종교들은 근본적으로 타 종교에 대해 서 유화적인 태도를 취하고 있다고 일컬어지지만, 이러한 진술은 그다 지 자명한 것으로 여겨질 수는 없을 것이다. 비록 표면적으로는 타종 교에 대해서 개방적인 태도를 취하고 있다고 하더라도, 본질적인 의미 에서 자신의 종교적 진리를 이해함에 있어서 타종교의 진리이해가 필 수적이라고 여겨지지 않는다면, 참다운 의미에서의 다원주의에 이르렀 다고 할 수는 없기 때문이다. 이런 점에서 헤이스의 다음과 같은 지적 은 타당하다.

“모든 종교들은 전통적으로 승리주의적이었으며 다원주의적 이 아니었다는 사실은 우리들이 정직하게 인정하지 않으면 안 되는 사실이다. 지금 우리들의 시대에서 환영받는 사고방식의 전조(前兆)를 전통 속에서 찾으려는 시도는 시대착오적이며 또 
대순사상에 있어서 종교다원주의 패러다임의 가능성에 대한 연구 / 김승철| 33

한 지적으로 성실하지 못하다. 왜냐하면 전통적인 사회는 우리 들이 사는 오늘날의 세계와는 전적으로 다른 사회적, 정치적 상 황 속에서 발전해왔기 때문이다.”55)

앞서 하이직이 대화의 직접을 대화를 둘러싼 기독교적 언설로 치환하 는 것을 “잘못 놓여진 대화의 직접성의 오류”(The misplaced immediacy) 라고 불렀듯이, 우리들은 위의 헤이스의 지적처럼, 종교적 다원성에 대한 자각을 전통 종교 그 자체에 환원시키려는 소박한 시도를 "역사적으로 구 체성을 잘못 놓은 오류”라고 부를 수 있을 것이다.

그러나 위의 헤이스의 지적은, 기독교적 실재이해로부터 종교다원 주의를 위한 패러다임의 도출이라는 현실적인 시도가 있었던 것처럼, 아시아의 종교이해로부터 종교다원주의적 패러다임의 가능성을 논하 려는 일체의 시도를 불가능하게 만드는 것은 물론 아니다. 왜냐하면, 헤이스의 지적이 현금의 종교다원주의를 둘러싼 논의를 어느 특정 전 통에서 직접적으로 유출할 수 있다는 주장을 금기시한다는 점에서는 타당성을 지닌다고 하겠으나, 종교다원주의를 위한 논의의 장은 논의 의 주체가 서 있는 역사적이고 해석학적인 장(場)일 수밖에 없다는 사 실을 암시하고도 있기 때문이다.

위의 헤이스의 지적이 타당하다고 한다면, 우리들은 한국의 신종교 운동에 포함되어 있는 종교사상이 현대의 종교다원주의를 위한 패러 다임이 되기 위해서는 다시금 창조적으로 재해석되어야 한다는 점이 다. 즉 대순사상을 포함한 한국의 신종교가 당시의 전통적인 아시아의 종교들을 창조적으로 재해석함으로써 당시의 민중들의 삶 속에 뿌리 를 내릴 수 있었던 것처럼, 오늘날 종교적으로 다원화된 사회적 현실 속에서 한국의 신종교는 또 한 번의 창조적 재해석이라는 과제에 직 면해 있다는 말이다.

한국의 신종교 운동의 일반적인 특징으로서 '삼교의 합일’이 중요한

55) Richard P. Hayes, "Gotama Buddha and Religious Pluralism”, Journal of Religious Pluralism 1 (1991), pp.94-95. 
요소로서 거론되는 것은 분명한 사실이겠으나, 거기에는 '후천개벽사 상'(後天開䦣思想)과 '선민(選民), 택지(擇地)사상’이 바탕이 되고 있는 것 또한 지적되고 있다. 즉 '삼교의 합일’이라는 사상이 오늘날 우리 들이 요청하는 종교다원주의라는 맥락에서 제기되었다기보다는 "조선 이라는 땅에 뿌리를 내린 모든 사상을 하나다.”라는 논지로부터 비롯 되었다고 해석될 수 있다면, 이는 신종교 운동에 있어서 “조선이라는 토지가 성성(聖性)을 띤 공간표상으로서 그려지고 있다.”는 사실과 일 치하며, 나아가 ‘삼교의 합일'이라는 사상에서 '선민, 택지사상'과의 직 접적인 연관성을 볼 수 있다.”는 점에서 새로운 검토를 요청하는 것이 다.56) 이는 한국 신종교 운동의 '중심축’으로서 '개벽사상(開闢思想)과 민족주체사상'이라고 보면서, “한국 신종교 운동에서 추출되는 모든 교리나 사상은 이 두 가지로 귀착될 수 있다.”는 노길명의 시각과 일 치한다.57) 더욱이 그는 "민족주체사상은 선민사상과 민족문화계승사 상을 통해서 나타난다.”고 지적한다. 이는 ‘삼교의 합일'이라는 사상이 - "전통종교의 교리나 사상은 물론 민중에 의해 전승되는 재래의 민 간신앙을 배척함 없이 거의 모두 수렴하고 있다.”는 사실과 더불어“한국의 종교적 유산들을 수렴하고 새롭게 체계화함으로써 문화적 정 체성을 확립시키고자 하는 강한 열의를 나타낸다.”고 하는 역사적 맥 락을 드러내주는 동시에, '삼교의 합일' 사상을 현금의 종교다원주의 를 위한 패러다임으로 연결시키기 위한 해석학적 시도가 불가결하다 는 점을 말해준다. 이는 구한말의 열강의 침략과 사회 내적인 모순에 직면하였던 상황에서 태동한 한국의 신종교가 지니는 역사적 구체성 과 직결되는 문제라고 할 수 있다. 이러한 위의 지적과 관련하여 노길 명이 한국 신종교 일반에 대해서 내리는 다음의 진단은 중요한 의미 가 있다고 하겠다.

56）丹犲泉,「韓国宗教の諸相：比較の視座をもとめて」, 『宗教研究』79-4（日本宗教学会, 2006), p.33.

57) 노길명, 앞의 글, p.601. 
“한국의 신종교 운동이 제시하는 가치나 이념에서는 인권, 사 회 정의, 인류 평화와 같은 보편적 가치와 함께, 근면, 금욕, 인 간애(人間愛), 공동선(共同善), 해원상생 등과 같은 윤리덕목이 강하게 포함되어 있다. 문제는 이와 같은 보편적 가치나 윤리덕 목을 어떻게 세계적으로 펼쳐나가느냐 하는 점이다. 이와 같은 점들에 충실하면서 세계사적 변화 흐름에 능동적으로 적응할 때에만 한국의 신종교는 세계종교, 즉 인류 보편의 종교로 발전 하게 될 것이다.”58)

한국의 신종교는, 세계의 모든 종교와 더불어, 끊임없는 "현대화" (aggiornamento)의 과제 앞에 서있다. “아지오르나르멘토”는 가톨릭 교회가 바티칸 제2공의회를 개최하면서 모토로서 내어걸었던 개념인 바, 그것은 과거의 것을 “오늘”(giorno)의 것으로 재해석하여 교회와 신앙을 갱신한다는 취지였다.[이 단어의 독일어역은 금일화(今日化, Verheutlichung)인데, 이는 본래의 의미에 더 충실한 번역이라고 하 겠다.]

그렇다면 한국의 신종교로부터 추론될 수 있는 종교다원주의를 위 한 패러다임은 어떠한 것이 될 수 있을까? 결론적으로 말해 본다면, 동양적 종교이해의 특징이기도 하며 또한 금일 구미의 신학자와 종교 학자들이 그 중요성과 현실성을 자각하고 있는 "동시에 복수의 종교 적 전통에 속하기"(multiple religious belonging)라는 종교성을 위해 서 대순사상을 포함한 한국의 신종교는 새로운 전개방향을 제시할 수 있으리라 여겨진다.

이에 대한 상세한 논의는 지면관계로 다음의 기회를 기할 수밖에 없으나, 중층적인 종교적 실존성, 즉 '중층신앙'은, 앞에서 일본의 신 학자 후루야의 말을 인용해서 언급했던 것처럼, "동시에 복수의 종교 의 신자"가 되는 것을 의미한다. 비록 의식적으로는 하나의 종교에 귀 의하고 있는 듯이 보인다고 하더라도, 아시아의 종교인은 그러한 자신

58) 같은 글, p.607. 
의 종교를 이해하기 위한 해석학적 지평으로서 다수의 종교적 전통 속에 놓여져 있다. 여기서 중요한 것은 그러한 다수의 종교적 전통이 자신의 신앙의 외부에 있는 것이 아니라, 자신의 신앙을 수행해 나가 는 과정에서 이미 자신의 신앙의 내부가 되어 있다는 사실이다. 아시 아의 신앙인에게 있어서 타종교는 그러므로 외부적인 타자가 아니라 “내부적인 타자'이다. 증산이 “관왕”(冠旺)과 “도솔”(皃率)이라는 개념 을 가지고 유, 불, 선이라는 '내부적 타자'를 자신의 신앙이라는 정점 에 이르는 과정으로 이해하였던 것도, 이러한 “동시에 복수의 종교적 전통에 속하기”에 대한 접근의 하나로서 이해될 수 있다. 이러한 이해 의 타당성은, 앞에서 몇몇 종교학자의 지적에서도 제기되었던 것처럼, 구한말이라는 역사적 배경 속에서 태동하였던 한국의 신종교가 현대 화라는 과제를 수행해 나가는 과정에 의해서 뒷받침되어야 할 것이기 도 할 것이다.

종교다원주의의 신학을 제창해 온 폴 니터는 그의 최근의 책인 『붓 다 없이 나는 그리스도인일 수 없었다』(Without Buddha I Could not be a Christian)이라는 책에서 우리들의 종교적 실존이 언제나 복수의 종교적 전통에 속한다(multiple religious belonging)59)는 사실을 다음 과 같이 기술하고 있다. 그의 주장은 종교적으로 다원화된 세계를 살 아온 한국의 종교인들의 종교성을 그려내 주는 언사라고 할 수 있다.

59) “동시에 복수의 종교적 전통에 속하기”(multiple religious belonging)라는 테마는 유럽과 미국의 신학자와 종교학자를 중심으로 활발히 논의되고 있는 주제이다. 이와 관련해서는 다음의 글을 참조하시오. Seung Chul Kim, ibid., p.28; Christoph Boc hinger, "Multiple religiöse Identitäten im Westen zwsichen Traditionsbezug und Individualisierung", in Reinhold Bernhardt/Perry Schmidt-Leukel hrsg., Multiple religiöse Identität. Aus verschiedenen religiösen Traditionen schöpfen (Zürich: Theologischer Verlag Zürich, 2008), S.137ff.; Jan Van Bragt, "Multiple Religio us Belonging of the Japanese People", Catherin Cornille ed., Many Mansions? Multiple Religious Belonging and Christian Identity (Orbis Books, 2002), pp.719; Cf. Xavier Gravend-Tirole, "Double Commiment: or The Case for Religious Mestizaje (Creolization)", in David Cheetham et. al. ed., Interreligious Hermen eutics in Pluralistic Europe: Between Texts and People (Editions Rodopi B. V., 2011), p.415ff. 
대순사상에 있어서 종교다원주의 패러다임의 가능성에 대한 연구 / 김승철| 37

“우리의 문화적, 사회적 자아처럼 우리의 종교적 자아도 그 핵심과 행동에서 하나의 혼종(hybrid)이다. 우리의 종교적 정체 성은 순종이 아니라 혼종이다. 단일한 것이 아니라 복수적인 것 이다. 종교적 정체성은 하나의 삶의 자리에서 다른 삶의 자리로 이동하고, 하나의 자아를 형성한 후 다른 자아들을 만나면서 본 래의 자아를 확장하거나 수정하는 지속적인 과정을 통해 형성 된다. 명료하게 정의되는 불변의 정체성 같은 것은 없다. 불자 들이 옳다. 분리되어 있고 불변하는 자아는 없는 것이다. 우리 는 종종 우리와 매우 다른 타자와 상호작용하는 혼종화 과정을 통해 끝없이 변화하고 있는 것이다."60)

종교적으로 다원화된 영향사(影響史)를 살면서 전통적인 종교를 창 조적으로 재해석하여 대중들에게 영향을 미쳐온 한국의 신종교가 이러 한 종교성을 설명해 줄 종교적 언어를 자체 안에 지니고 있음은, 한국 의 신종교가 현대의 종교다원주의를 위해서 공헌할 가능성을 지니고 있음을 말해주고 있다고 하겠다. 대순사상이 지닌 현대적 의미에 대한 연구는 이러한 의미에서도 지속적으로 수행되어야 하리라 믿는다.

60 ) 폴 니터, 『붓다없이 나는 그리스도인일 수 없었다』, 정경일 - 이창엽 옮김 (서울: 클리어마인드, 2011), p.389. 


\section{【참 고 문 헌 】}

대순진리회 교무부, 『전경』, 서울: 대순진리회 출판부, 1989.

김승철, 「무주(無住)와 방황(彷得): 즉비(䛜非)의 논리와 해체의 신학」, 『종교신학연구』8, 1995.

「종교다원주의와 한국신학의 방향」, 우리사상연구소 편, 『한 국 가톨릭 어디로 갈 것인가』, 서울: 서광사, 1997.

「E・トレルチの神学思想におけるヨーロッパ中心主義について」, 『金城学院大学論集』, 7-1, 2010.

김승철 편역, 『종교다원주의와 기독교 $1 \unlhd$, 서울: 나단, 1993. 노길명, 「한국 신종교 운동의 성격」, 『대순사상논총』 $7,1999$. 박광수, 「한국 신종교의 근본주의(Fundamentalism)와 회통적 다원주 의(Synthetic Pluralism)」, 『한국종교연구』9, 2007.

박마리아, 「포스트모던사회와 대순진리회: 다원성의 구현을 중심으로」 『신종교연구』20, 2009.

Vatican Council, 『제2차 바티칸 공의회 문헌 (헌장, 교령, 선언문)』, 서울: 한국천주교중앙협의회, 1969.

Straelen, H.v. 편, 『공의회문헌 해설총서』1, 현석호 역, 서울: 성바오 로출판사, 1982.

유동식, 『풍류신학으로의 여로』, 서울: 전망사, 1988.

이경원, 「대순사상의 삼교관왕론 연구」, 『신종교연구』 $17,2007$.

『한국 신종교와 대순사상』, 서울: 문사철, 2011.

『대순진리회의 신앙론』, 서울: 문사철, 2012.

이진재, 「원불교 사상에 나타난 유·불·선 삼교회통에 관한 소고」, 『원 불교학연구』17, 1987.

장병길, 『한국 종교와 종교학』, 서울: 청년사, 2003.

폴 니터, 『붓다없이 나는 그리스도인일 수 없었다』, 정경일, 이창엽 옮김, 서울: 클리어마인드 지오비스, 2011. 
대순사상에 있어서 종교다원주의 패러다임의 가능성에 대한 연구 / 김승철| 39

Alan Race, Christians and Religious Pluralism: Patterns in the Christian theology of religions, N.Y.: Orbis Books, 1983.

Axel Michaels, "Einleitung” idem (Hg.), Klassiker der Religions wissenschaft: Von Friedrich Schleiermacher bis Mircea Eliade, 2.Aufl., München: C.H.Beck, 2004.

Ernst Troeltsch, Die Absolutheit des Christentums und die Religions geschichte, J.C.B. Mohr, 1902.

Ernst Troeltsch, Meine Bücher (1922) in: Gesammelte Schriften Band IV. Aufsätze zur Geistesgeschichte und Religionssoziologie hg.v. Hans Baron, J.C.B.Mohr Verlag, 1925.『私の著書』，荒木康 彦訳, 大阪：創元社, 1982.

Friedrich Heiler, Erscheinungsformen und Wesen der Religion, Stuttgart: W. Kohlhammer Verlag, 1961.

James W. Heisig, "The Misplaced Immediacy of Christian-Buddhist Dialogue”, in Catherin Cornille and Stephanie Corigliano (ed.), Interreligious Dialogue and Cultural Change, Eugene, OR: Wipf and Stock Publishers, 2012.

John Hick, A Christian Theology of Religions: The Rainbow of Faiths, KY: Westminster John Knox Press, 1995.

Kim, Seung Chul, "How could we get over the monotheistic paradigm for the interreligious dialogue", Joumal of Inter-religious Studies 13, 2014.

Mark C. Taylor, Erring: A Postmodern a/theology, Chicago: University of Chicago Press, 1987

Paul F. Knitter, No Other Name? A Critical Survey of Christian Attitudes Towards World Religions, N.Y.: Orbis Books, 1985.

Richard P. Hayes, "Gotama Buddha and Religious Pluralism”, Journal of Religious Pluralism 1, 1991. 
Robert E. Buswell Jr., "Introduction: The Life and Thoughts of Chinul”, The Korean Approach to Zen: The Collected Works of Chinul, tr. by Robert E. Buswell Jr, Honolulu: University of Hawaii Press, 1983.

S.N. Balagangahara, Reconceptualizing India Studies, Oxford: Oxford University Press, 2012.

古屋安雄, 『現代キリストと将来』, 東京: 新地書房, 1984.

磯前順一,「宗教研究とポストコロニアル状況」磯前順一・タラル・アサ

ド編『宗教を語りなおすー近代的カテゴリーの再考』, みすず書 房、2006.

丹犲泉, 「韓国宗教の諸相 : 比較の視座をもとめて」, 『宗教研究』79-4, 日本宗教学会, 2006.

島田勝巳,「天理教学』の生成と展開 : 媒介としての宗教諸学の意義をめ ぐって」, 『天理教学研究』43, 2009.

東馬場郁生, 「天理教の「諸宗教の教学」への試み」、天理大学学報』56-11, 2004.

天理敉呚會本部編, 『天理呚敎典』, 天理: 天理敉道友社, 2012. 海老沢有道, 『日本キリシタン史』, 東京: 塙選書, 1966 . http://www.liu.se/irk/religion/texter/EA/EA99omSoderblom.htm (2010년4월22일) 
-Abstract

\title{
大巡思想における宗教多元主義的パラダイムの 可能性についての研究
}

\author{
金承哲 \\ 南山大学・南山宗教文化研究所第一種研究所
}

この論文は、これまで主にキリスト教种学を中心にして展開されてきた 宗教多元主義をめぐる議論を批判的に考察し、真の諸宗教対話に基づく宗 教多元主義の新しいパラダイムを模索したものである。周知の通り、キリ スト教においては、バチカン第二公会議の『非キリスト教についての教会 の態度』(Nostra Aetate) が宣言された以来、諸宗教についての対話的・ 開放的理解を目指してきた。こうした意味で、『非キリスト教についての 教会の態度』がもたらした画期的意義は、十分認められるべきである。し かしながら、その宣言が含んでいる神学的パラダイムについても、また、 キリス卜教中心的な諸宗教対話については、多くの批制が寄せられている のも事実であろう。というのは、宗教多元主義が本来の意味で議論される ためには、諸々の宗教自らが諸宗教についての理解を積極的に表明しなけ ればならないからである。

この論文は、上記のような歴史的・宗教的問題意識に着目して、韓国の 新宗教としての大巡思想の諸宗教観について検討し、その思想が昨今の宗 教多元主義をめぐる議論に積極的に貢献できるかについて論じたものであ る。大巡思想は、旧韓末という歴史的・社会的・宗教的文脈の中で生まれ な宗教として、現代社会においても、人々の宗教的ニーズに応えられる宗 
教思想を露呈していると思われる。とりわけ、大巡思想が宗教的理念とし て教える「解冤相生」の概念や、歴史を「天尊時代」から「地德時代」を 経て「人尊時代 への動きとして解く歴史観は、新たに注目される必要が ある。なぜならば、諸方面における葛藤や対立の解決を課題としている現 代社会においてこそ、多元化された生き方や考え方を切実に要求するから である。さらに、こうした大巡思想の「解冤相生」の教えは、宗教多元主 義のための新しいパラダイムを提供する可能性をもつと同時に、韓国の伝 統的な宗教理解として言われる「宗教の円融」という思想にも、新たな解 釈の道を与えていると思われる。

Key words : 大巡思想, 宗教多元主義, キリス卜教, 新宗教, 解冤相生, 混合主義, 宗教の現代化(aggionarmento)

() 투 고 일 : 2014년 10월 31일

() 심 사 기 간 : 2014년 12월 19일 28일

() 게 재 확 정 일 : 2014년 12월 29일 